\title{
Rehabilitation Program in a Patient Undergoing Mitral and Aortic Valve Replacement Surgery
}

\author{
Purwati Pole Rio*, Muhamad Taufik Ismail, Irsad Andi Arso
}

\author{
Department of Cardiology and Vascular Medicine, Faculty of Medicine, Universitas Gadjah Mada University - Dr. Sardjito \\ General Hospital, Yogyakarta, Indonesia \\ ${ }^{*}$ Corresponding author: \\ Purwati Pole Rio, MD - email: purwatipolerio@yahoo.com \\ Department of Cardiology and Vascular Medicine, Faculty of Medicine, Universitas Gadjah Mada - Dr. Sardjito Hospital, \\ Jalan Farmako Sekip Utara Yogyakarta, 55281, Indonesia.
}

Manuscript submitted: October 01, 2017; Revised and accepted: October 29, 2017

\begin{abstract}
Heart disease due to valvular anomaly has increased prevalence along with increasing age. The operative management including reparation or substitution with prosthetic valve is the main therapy. Still becoming question mark either rehabilitation program is beneficience for patient undergoing valvular surgery. We report a patient with heart failure due to valvular heart disease and underwent double valve replacement surgery. Cardiac rehabilitation phase 1 and phase 2 was done. Patient feel physical condition is much better than before.
\end{abstract}

Keywords: rehabilitation; valvular heart surgery; heart failure

\section{Intisari}

Penyakit jantung yang terkait kelainan katup memiliki prevalensi yang meningkat seiring peningkatan usia. Penanganan secara operasi termasuk perbaikan atau penggantian dengan katup prostetik merupakan terapi utama. Masih menjadi tanda tanya apakah program rehabilitasi bermanfaat bagi pasien yang menjalani operasi katup. Dilaporkan pasien dengan gagal jantung yang disebabkan oleh penyakit katup jantung dan menjalani pembedahan penggantian dua katup. Rehabilitasi jantung fase 1 dan fase 2 dilakukan di rumah sakit dan di rumah secara terprogram. Pasien merasa kondisi fisik jauh lebih bugar dibanding sebelumnya.

\section{INTRODUCTION}

Heart disease duea to valvular anomaly has prwvalence of $2.5 \%$ in USA with prevalence $0.7 \%$ in population in population aged $18-44$ year old and increasing $13.3 \%$ in population aged > 75 year old. ${ }^{1}$ Symptomatic valvular heart disease can affect quality of life. Operative management, either replacement or reparation is the first choice of treatment. Clinical guideline that emphasizing the importance of rehabilitation post valvular operation is still rare. The current guideline is come from randomized trial done in coronary heart disease or congestive heart failure. It is still a question mark either similar result will be found in population undergoing valvular operation.

\section{CASE PRESENTATION}

A male aged 42 year old with body mass indext $23.4 \mathrm{~kg} / \mathrm{m}^{2}$ has chief complaint of dyspneu on effort since 5 years before entering hospital. $\mathrm{He}$ also complaining of orthopneu, paroxysmal nocturnal dyspneu, and extremity swelling. No complaint of chest pain, syncope, and dizziness. An echocardiography examination done show all camber dilatation, mitral valve has hockey stick appearance, thickened with Wilkins score 10, MVA planimetry $0.9 \mathrm{~cm}^{2}$, MVAPHT $0.5 \mathrm{~cm}^{2}$, MVmeanPG $14.66 \mathrm{mmHg}$, and MV max PG $21.15 \mathrm{mmHg}$. The aortic valve has calcification in all cuspis with AVA planimetry $1.1 \mathrm{~cm}^{2}$, AVA VTI $1.3 \mathrm{~cm}^{2}$, AV mean PG $16.54 \mathrm{mmHg}$, and AV max PG $28 \mathrm{mmHg}$. Tha 
aortic valve also has regurgitation with ARPHT 498 ms. Tricuspid valve examination shows severe regurgitation with TVG $82 \mathrm{mmHg}$. Interventricular septum has paradoxical movement with ejection fraction 55\%, TAPSE 15, diastolic function could not be measured because patient has atrial fibrillation. Surgical conference done decided to do double valve replacement and tricuspid valve repair on this patient.

An aortic and mitral valve replacement surgery was done on October 2016. The aortic and mitral valve was replaced with mechanical prostethic valve, aortic valve with Sorin no.23 and mitral valve with Sorin no.27, and De Vega procedure was done to tricuspid valve. The surgery run well with aortic cross clamp time 147 min, cardiopulmonary bypass time $187 \mathrm{~min}$, and ischemic time $141 \mathrm{~min}$.

The patient then admitted to Intensive Care Unit for 2 days. Echo evaluation shows mild hypokinetic of the left ventricle with ejection fraction 45\%, TAPSE $14 \mathrm{~mm}$, prosthetic mitral valve show good movement, no perivalvular leakage, MVAVTI $2.1 \mathrm{~cm}^{2}$. Aortic valve evaluation shows a good movement, no perivalvular leakage, only mild regurgitation found, AVA VTI $1.75 \mathrm{~cm}^{2}$. Tricuspid valve examination shows severe regurgitation with TVG $78 \mathrm{mmHg}$, homodynamic measurement at that time found CO $9 \mathrm{l} / \mathrm{min}, \mathrm{Cl} 5.3 \mathrm{~L} / \mathrm{min} / \mathrm{m}^{2}$, and SVR 530 dynes sec $\mathrm{cm}^{-5}$. Patient then moved to ICCU for 7 days.

Cardiac rehabilitation phase started in this patient since day 3 in ICCU. Physical exercise start from moving legs and arms actively in day 3 to 6 , siting exercise on day 7 to 9 , standing and walking exercise on day 10 in ICCU. No complication on surgical woud, hemodynamic was stabile, and no post operative infection.UFH was given on day 3 intravenously concomitant with oral warfarin $2 \mathrm{mg}$, UFH was stopped once INR achieved.

Before discharge, an exercise called six minutes walk test (6MWT) was done in order to determine exercise prescription in phase 2.
In 6MWT, the patient can walk as far as $400 \mathrm{~m}$ in 5 minutes, no chest pain, borg scale was 10 . From this result, we calculate VO2 Max was 3 METS (10.5 ml/kg/min). Clinical data and 6MWT result shows the patient were in moderate risk stratification to do the exercise in phase 2 cardiac rehabilitation program.

Phase 2 rehabilitation program take place in rehabilitation polyclinic in Sardjito hospital. The patient do 3 times a week supervised exercise with 4 weeks duration, total 12 times supervised exercise. The exercise intensity based on risk stratification on in $6 \mathrm{MWT}$, so $65 \%$ from initial maximum walking distance were given, so the walking distance is $1300 \mathrm{~m}$ in 30 minutes, divided into 2 doses, each 15 minutes. Duration during first 2 weeks exercise is 2 times 15 minutes with 5 minutes break time in between, with walking exercise where walking distance will be increased progressively as much as $5-20 \%$ each week. In the first meeting, the patient able to walk $650 \mathrm{~m}$ in 15 minutes without complaint, then the next exercise walking distance increased step by step. In each session, education about oral anticoagulant as thrombosis prevention in prosthetic valve also given.

In the last session of supervised exercise, treadmill evaluation was done and the result was negative ischemic response, normal hemodynamic response, average fitness, and aerobic capacity was 7.23 METS $(25.3 \mathrm{ml} /$ $\mathrm{kg} / \mathrm{min}$ ). For continuation of phase 2 exercise program in patient house, patient is in moderate risk stratification, so given $60 \%$ intensity which is 4.78 METS. Heart rate exercise target calculated using Carvonen method as much as $60 \%-70 \%$ is 140 to $150 \mathrm{x} / \mathrm{min}$. Patient was advised to do exercise program as many as 3 to 5 times a week by jogging with speed $3.9 \mathrm{~km} / 30$ min or cycling with target $7.8 \mathrm{~km} / 30$ minutes. Patient feel physical condition is more fit compared with before exercise, and the dyspneu diminished. Patient also was given education about routine 
daily acivity that can be done actively in house as part of phase 3 rehabilitation program, and also given education about consumption of anticoagulant and monitoring as secondary prevention of valvular thrombosis.

\section{DISCUSSION}

According to $\mathrm{WHO}$, rehabilitation in patient having cardiac disease is several activities done in order to help improving the underlying disease, including infrease physical, mental, and social condition, in order to make patient able to function normally in society. A RCT by Landry et al reporting 20 patient post aortic valve replacement shows increase in maximum oxygen uptake (VO2 maks) upto $5.0 \mathrm{ml} / \mathrm{kg} / \mathrm{min}$ $(23 \%)$ after physical exercise $(p \leq 0.01) .{ }^{2} \mathrm{An}$ observational study by Habel-verge found from 19 womens undergoing mitral valve replacement, there is VO2 average increase as much as 4.0 $\mathrm{mL} / \mathrm{kg} / \mathrm{min}$. ${ }^{3}$ Newell et al. found similar result from randomized trial with 24 patients undergoing mitral or aortic valve replacement, an increase in cardiorespiratory fitness found in 12 and 24 weeks after operation in group undergoing physical exercise. ${ }^{4}$ Evaluation of functional capacity post valvular operation done by Niemela et al also shows increase in ejection fraction of left ventricle and decrese of New York Heart Association Class with physical exercise. ${ }^{3}$ Sire et al. also found increase in functional capacity as much as $38 \%$ in 6 months post operation in 44 patients undergoing physical examination. Jaraith et al also found increase in VO2 maks as much as $25 \%$ after 3 months physical exercise. ${ }^{5}$ A study by Sibilitz et al in 147 patients undergoing balbular replacement after intervention in form of physical exercise and physcicological consultation found increase in VO2 maks after 4 months intervention compared with control (24.8 $\mathrm{mL} / \mathrm{kg} / \mathrm{min}$ vs $22.5 \mathrm{~mL} / \mathrm{kg} / \mathrm{min}, \mathrm{p}=0.045) .{ }^{6}$

Cardiac rehabilitation consisted of 3 phases, phase 1 is rehabilitation during hospitalitation, phase 2 is outpatient rehabilitation, and phase 3 is is long term rehabilitation. In patient undergoing valvular replacement operation, physical rehabilitation phase 1 can be started as early as possible, which is 48 hours after operation if no complication found. Before rehabilitation phase 1 started, clinical assessment which include disease history, medical condition, risk factor, and intervention that have been done, also comorbid during hospitalization need to be assessed.

\section{CONCLUSION}

A male, 42 year old diagnosed with chronic heart failure due mitral stenosis and regurgitation, aortic stenosis and regurgitation, and tricuspid regurgitation. This patient undergone double valve replacement of aortic and mitral valve and also tricuspid repair. Initial assessment of phase 2 rehabilitation done before hospital discharge reveal aerobic capacity 3.0 METS $(10.5 \mathrm{ml} /$ $\mathrm{kg} / \mathrm{min}$ ). Supervised rehabilitation program conducted progressively in 12 meetings result in improvement of arobic capacity become 7.23 METS ( $25.3 \mathrm{ml} / \mathrm{kg} / \mathrm{min}$ ). Rehabilitation program shown to increase functional capacity and fitness in this patient.

\section{REFERENCES}

1. D'Arcy JL, Prendergast BD, Chambers CB, Ray G. 2011. Valvular heart disease: the next cardiac epidemic. Heart; 97:91-93.

2. Landry F, Habel C, Desaulniers D, Dagenais GR, Moisan A, Cote L. 1984. Vigorous physical training after aortic valve replacement: Analysis of 10 patients. Am J Cardiol; 53:562-566.

3. Sibilitz KL, Berg SK, Hansen TB. Effect of comprehensive cardiac rehabilitation after heart valve surgery (CopenHeartVR): study protocol for a randomized clinical trial. BioMed Central; 14:104. 
4. Newell JP, Kappagoda CT, Stoker B, Deverall PB, Watson DA, Linden R. 1980. Physical training after heart valve replacement. $\mathrm{Br}$ Heart J; 44:638-649.

5. Barwalf CG. 2007. Exercise training in Valvular Disease in Perk J, Mathes $P$, Gohlke H, Monpere C, Hellemans I, et al. (eds): Cardiovascular Prevention and Rehabilitation. London: Springer-Verlag.

6. Sibilitz K, Berg SK, Rasmussen TB. 2016. Cardiac rehabilitation increases physical capacity but not mental health after heart valve surgery: A randomized clinical trial. Heart; 102:1995-2003. 